\title{
Article \\ Analysis of Biodiesel Influence on Unregulated Gaseous Emissions of Diesel Motor Vehicles
}

\author{
Michal Puškár ${ }^{1}$, Jozef Živčák ${ }^{1}$, Štefan Král ${ }^{2}$, Melichar Kopas ${ }^{1}$ and Matúš Lavčák ${ }^{1, *}$ \\ 1 Faculty of Mechanical Engineering, TU Košice, Letná 9, 04001 Košice, Slovakia; \\ michal.puskar@tuke.sk (M.P.); jozef.zivcak@tuke.sk (J.Ž.); melichar.kopas@tuke.sk (M.K.) \\ 2 The Slovak Legal Metrology (SLM), Hviezdoslavova 1124/31, 97401 Banská Bystrica, Slovakia; kral@slm.sk \\ * Correspondence: matus.lavcak@tuke.sk
}

Citation: Puškár, M.; Živčák, J.; Král, Š.; Kopas, M.; Lavčák, M. Analysis of Biodiesel Influence on Unregulated Gaseous Emissions of Diesel Motor Vehicles. Appl. Sci. 2021, 11, 4646. https://doi.org/10.3390/app11104646

Academic Editor: Andrew May

Received: 23 March 2021

Accepted: 16 May 2021

Published: 19 May 2021

Publisher's Note: MDPI stays neutral with regard to jurisdictional claims in published maps and institutional affiliations.

Copyright: (c) 2021 by the authors. Licensee MDPI, Basel, Switzerland. This article is an open access article distributed under the terms and conditions of the Creative Commons Attribution (CC BY) license (https:// creativecommons.org/licenses/by/ $4.0 /)$.

\begin{abstract}
This scientific study is focused on the analysis of an influence of the experimental diesel fuel mixtures containing various portions of the biocomponent on the unregulated gaseous emissions generated by a diesel motor vehicle, which is equipped with the diesel engine utilizing the direct fuel injection system "common rail". The main reason for the choice of this engine type was its wide usage in the current vehicles. The experimental diesel fuel mixtures were created as a mixture of the standard low-sulfur diesel fuel with the biodiesel, using various mixing ratios. The experiments were realized by means of a special 13-regime engine test cycle, which was intentionally developed for the diesel combustion engines. All the individual experiments were performed on the base of the given test cycle with 13 different operational modes. The obtained results offer a complex view on the generation of the unregulated emissions with regard to the operational conditions and taking into consideration operational loading of the given experimental engine.
\end{abstract}

Keywords: analysis; biodiesel; unregulated emissions; motor vehicles

\section{Introduction}

Constantly growing energy consumption and the degradation of environmental quality require the search for alternative fuels in order to replace the petroleum fuels that are used nowadays in motor vehicles. One of the most often applied alternative fuels is biodiesel. The main advantage of biodiesel is its renewability and reduction in greenhouse gases [1]. Biodiesel can be used either in its pure form or in the form of diesel mixtures. For that reason, there have been various studies focused on diesel engines, which combust diesel mixtures. In general, it is possible to say that the application of biodiesel causes an increase in fuel consumption, reduction in HC emissions, $\mathrm{CO}$ emissions and particulate matter emissions as well as a moderate higher amount of $\mathrm{NO}_{\mathrm{x}}$ emissions [2-6]. The influence of unregulated emissions was also investigated by Sharp et al. [7] using three diesel engines. They recorded the reduced emissions of hydrocarbon and acetaldehyde. The USEPA [8] also presents lower levels of acetaldehyde, formaldehyde and xylene. According to McGill et al. [9] the interesting unregulated emissions, namely aldehyde and 1,3-butadiene, are almost independent on the kind of fuel. Di et al. [10] performed investigations with the following results: the reduced amount of formaldehyde, 1,3-butadiene, toluene and xylene, and the increased amount of acetaldehyde and benzene. Lapuerta et al. [11] stated a lack of published scientific research information concerning the impact of biodiesel on unregulated emissions. Taking into consideration all the abovementioned facts, we can say that it is necessary to carry out another scientific research works oriented around unregulated gaseous emissions of automotive diesel engines. In order to supplement a gap of knowledge in this area, in our study, the unregulated gaseous emissions of diesel engines are invesigated by means of a special 13-regime test cycle, which was directly developed for the diesel engine. The analyzed unregulated emissions 
include formaldehyde, acetaldehyde, 1,3 butadiene, propene, benzene, toluene and xylene. All these matters are classified as substances harmful for the atmosphere.

\section{Experiment Conditions}

The practical base for the experimental measurements created a diesel engine equipped with a direct fuel injection system of the common rail type, which is normally installed in a wide range of diesel engine vehicles. The tested diesel mixtures were achieved by mixing biodiesel with pure diesel using various mixing ratios. The pure diesel fuel contained less than $10 \mathrm{ppm}$ of the sulfur, such that it was the so-called ultra-low sulfur diesel (ULSD-F). Biodiesel was obtained from waste oil according to the valid European standard EN14214. The individual diesel mixtures were determined, taking into consideration the previous experiments, as follows: B-U (25:75) (25\% biodiesel and 75\% ULSD-F), B-U (50:50), B-U (75:25). The most important technical parameters of the tested diesel engine are summarized in Table 1.

Table 1. The experimental engine parameters.

\begin{tabular}{cc}
\hline Type & 4-Cylinders, Common-Rail Diesel \\
\hline Compression ratio (CR) & $16.2: 1$ \\
\hline Bore $\times$ stroke & $81 \times 95.5 \mathrm{~mm}$ \\
\hline Displacement & $1968 \mathrm{~cm}^{3}$ \\
\hline Rated output & $110 \mathrm{~kW}$ \\
\hline Engine speed & $3500-4000 \mathrm{rpm}$ \\
\hline
\end{tabular}

The experimental testing system was created by the placement of the tested diesel vehicle engine on the testing dynamometer according to Figure 1 . The gas analyzer was used to perform analysis of regulated gaseous emissions, i.e., for the analysis of nitrogen oxides $\left(\mathrm{NO}_{\mathrm{X}}\right)$, hydrocarbons $(\mathrm{HC})$, carbon monoxide $(\mathrm{CO})$ and particulate matter $(\mathrm{PM})$.

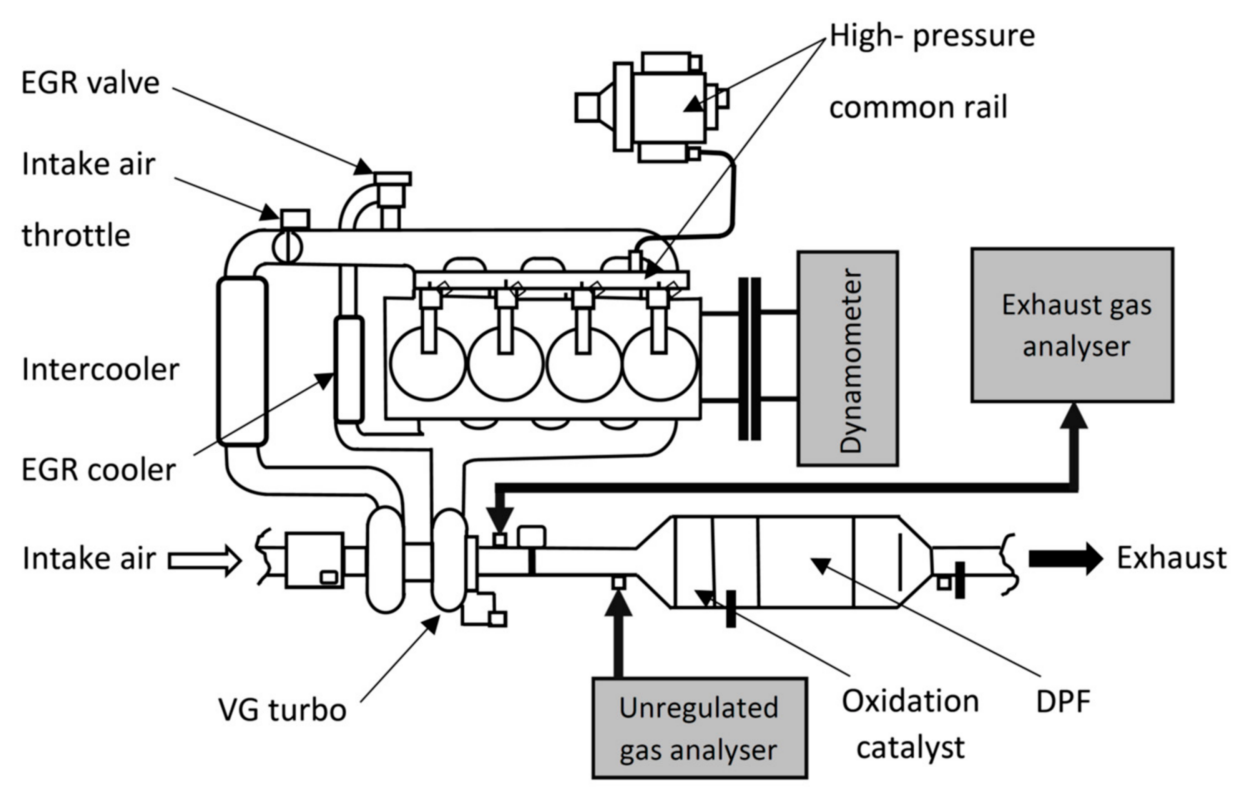

Figure 1. The experimental system.

Analysis of unregulated emissions (such as acetaldehyde, 1,3-butadiene, formaldehyde, ethene, propene and BTX hydrocarbons) was performed using the multi-component gas analyzer. The calibration of this analyzer was repeated before each measurement. The fuel consumption was measured by the electronic flowmeter. The characteristics of the experimental biodiesel and ULSD-F are presented in Table 2. 
Table 2. The characteristics of the experimental fuels.

\begin{tabular}{ccc}
\hline & Biodiesel & ULSD-F \\
\hline Density, $15\left(\mathrm{~kg} \cdot \mathrm{m}^{-3}\right)$ & $860 \div 920$ & $820 \div 845$ \\
\hline Viscosity $\left(40{ }^{\circ} \mathrm{C}\right)\left(\mathrm{mm}^{2} \cdot \mathrm{s}^{-1}\right)$ & $3.8 \div 5.1$ & $1.9 \div 4.1$ \\
\hline Cetane number & $\min 55$ & $\min 47$ \\
\hline Sulphur content $\left(\mathrm{mg} \cdot \mathrm{kg}^{-1}\right)$ & $\max 10$ & $\max 10$ \\
\hline Heat of evaporation $\left(\mathrm{kJ} \cdot \mathrm{kg}^{-1}\right)$ & $252 \div 295$ & $285 \div 338$ \\
\hline Flash point $\left({ }^{\circ} \mathrm{C}\right)$ & 103 & 82 \\
\hline Carbon content $(\mathrm{wt} \%)$ & 81.6 & 13.4 \\
\hline Hydrogen content $(\mathrm{wt} \%)$ & 12.4 & 0 \\
\hline Oxygen content $(\mathrm{wt} \%)$ & 10.5 &
\end{tabular}

The European Stationary Cycle (ESC) was used in order to analyze the influence of the fuel mixtures on the gaseous emissions. The ESC testing parameters are described in Table 3 and in Figure 2. The first regime of the testing process measurement was the stable operation of the tested engine. This first phase is characterized by the constant temperature of the coolant, lubricating oil and exhaust gases. Afterwards, the engine operational parameters were monitored at five-minute intervals; namely in the form of mean values of the measured operational parameters. The experiments were repeated two times with regard to the elimination of potential random failures. The results obtained from the experiments agree with the $97 \%$ confidence level.

Table 3. The European Stationary Cycle (ESC) test regimes.

\begin{tabular}{ccccc}
\hline Mode & Engine Speed & Load (\%) & Weight (\%) & $\begin{array}{c}\text { Duration } \\
\text { (min) }\end{array}$ \\
\hline 1 & Low idle & 0 & 15 & 4 \\
\hline 2 & A & 100 & 8 & 2 \\
\hline 3 & B & 50 & 10 & 2 \\
\hline 4 & B & 75 & 10 & 2 \\
\hline 5 & A & 50 & 5 & 2 \\
\hline 6 & A & 75 & 5 & 2 \\
\hline 7 & A & 25 & 5 & 2 \\
\hline 8 & B & 100 & 9 & 2 \\
\hline 9 & B & 25 & 10 & 2 \\
\hline 10 & C & 100 & 5 & 2 \\
\hline 11 & C & 25 & 5 & 2 \\
\hline 12 & C & 75 & 5 & \\
\hline 13 & C & 50 & & 5 \\
\hline
\end{tabular}




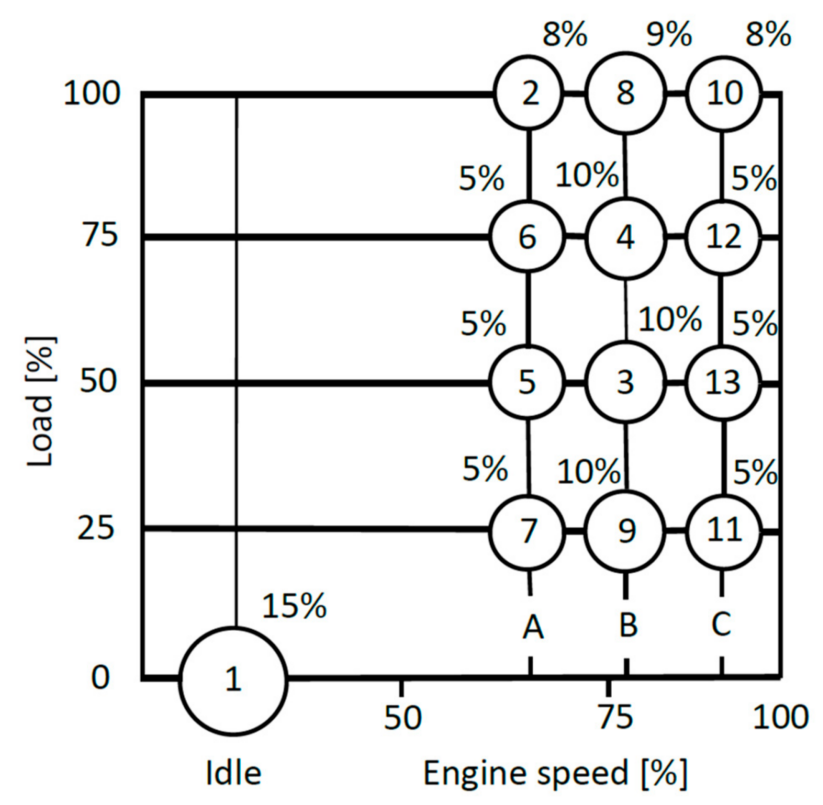

Figure 2. European Stationary Cycle (ESC).

\section{Results and Discussion}

\subsection{Parameters of the Experimental Engine}

Table 4 presents the fuel consumption (FC), given in $\mathrm{kg} / \mathrm{h}$, for the individual fuel mixtures. The values of the brake thermal efficiency (BTE) were calculated using data of the engine speed, torque and fuel consumption. It is evident that the combustion of biodiesel increases the fuel consumption, because the biodiesel heat value is lower compared to the standard diesel fuel. At the same time, the combustion of biodiesel increases the BTE thanks to a higher amount of oxygen in this fuel, which has a positive effect on the speed and quality of the combustion process. It is also possible to say that a higher level of the engine speed also increases the fuel consumption and reduces the BTE values. On the other hand, the BTE values are higher if the engine loading is rising. The above-mentioned facts are valid for both kinds of the fuels, i.e., for diesel fuel and for biodiesel, as well.

Table 4. The FC and BTE.

\begin{tabular}{ccccccccccc}
\hline Mode & \multicolumn{2}{c}{ ULSD-F } & \multicolumn{2}{c}{ B-U (25:75) } & \multicolumn{2}{c}{ B-U (50:50) } & \multicolumn{2}{c}{ B-U (75:25) } & \multicolumn{2}{c}{ Biodiesel } \\
\hline & $\begin{array}{c}\text { FC } \\
\mathbf{( k g} / \mathbf{h})\end{array}$ & $\begin{array}{c}\text { BTE } \\
\mathbf{( \% )}\end{array}$ & $\begin{array}{c}\text { FC } \\
\mathbf{( k g} / \mathbf{h})\end{array}$ & $\begin{array}{c}\text { BTE } \\
\mathbf{( \% )}\end{array}$ & $\begin{array}{c}\text { FC } \\
\mathbf{( k g} / \mathbf{h})\end{array}$ & $\begin{array}{c}\text { BTE } \\
\mathbf{( \% )}\end{array}$ & $\begin{array}{c}\text { FC } \\
\mathbf{( k g / h )}\end{array}$ & $\begin{array}{c}\text { BTE } \\
\mathbf{( \% )}\end{array}$ & $\begin{array}{c}\text { FC } \\
\mathbf{( k g} / \mathbf{h})\end{array}$ & $\begin{array}{c}\text { BTE } \\
\mathbf{( \% )}\end{array}$ \\
\hline 1 & 0.68 & & 0.70 & & 0.73 & & 0.77 & & 0.85 & \\
\hline 2 & 2.18 & 25.01 & 2.21 & 25.30 & 2.25 & 25.62 & 2.35 & 25.92 & 2.43 & 26.12 \\
\hline 3 & 3.31 & 33.15 & 3.32 & 33.40 & 3.44 & 33.52 & 3.54 & 33.82 & 3.69 & 34.31 \\
\hline 4 & 0.67 & & 0.70 & & 0.72 & & 0.77 & & 0.83 & \\
\hline 5 & 3.64 & 23.31 & 3.70 & 23.51 & 3.81 & 23.52 & 3.98 & 23.69 & 4.14 & 23.83 \\
\hline 6 & 5.49 & 31.04 & 5.56 & 31.25 & 5.70 & 31.43 & 5.92 & 31.73 & 6.15 & 31.92 \\
\hline 7 & 8.02 & 27.22 & 8.25 & 27.32 & 8.37 & 27.62 & 8.37 & 27.62 & 9.02 & 28.01 \\
\hline 8 & 11.00 & 30.19 & 11.18 & 30.38 & 11.36 & 30.48 & 11.36 & 30.48 & 12.18 & 31.05 \\
\hline 9 & 7.62 & 33.61 & 7.79 & 33.87 & 7.92 & 34.00 & 7.92 & 34.00 & 7.97 & 34.93 \\
\hline 10 & 9.73 & 35.13 & 9.89 & 35.33 & 10.11 & 35.52 & 10.11 & 35.52 & 10.87 & 36.12 \\
\hline 11 & 11.21 & 34.24 & 11.38 & 34.20 & 11.72 & 34.19 & 11.72 & 34.19 & 12.60 & 34.78 \\
\hline 12 & 14.78 & 29.95 & 14.91 & 30.19 & 15.24 & 30.29 & 15.24 & 30.29 & 16.41 & 30.79 \\
\hline 13 & 2.18 & 9.52 & 2.31 & 9.34 & 2.46 & 9.14 & 2.46 & 9.14 & 2.65 & 9.32 \\
\hline
\end{tabular}




\subsection{The Regulated Emissions}

The regulated emissions that are analyzed in this article include: $\mathrm{HC}, \mathrm{CO}$ and $\mathrm{NO}_{\mathrm{X}}$. The obtained results are shown in Figures 3-5.

It is evident from the analysis presented in Figure 3 that combustion of the fuel with a portion of biodiesel reduces the HC emissions under all conditions due to the oxygen, which is contained in biodiesel; thus, it increases the fuel combustion efficiency [12].

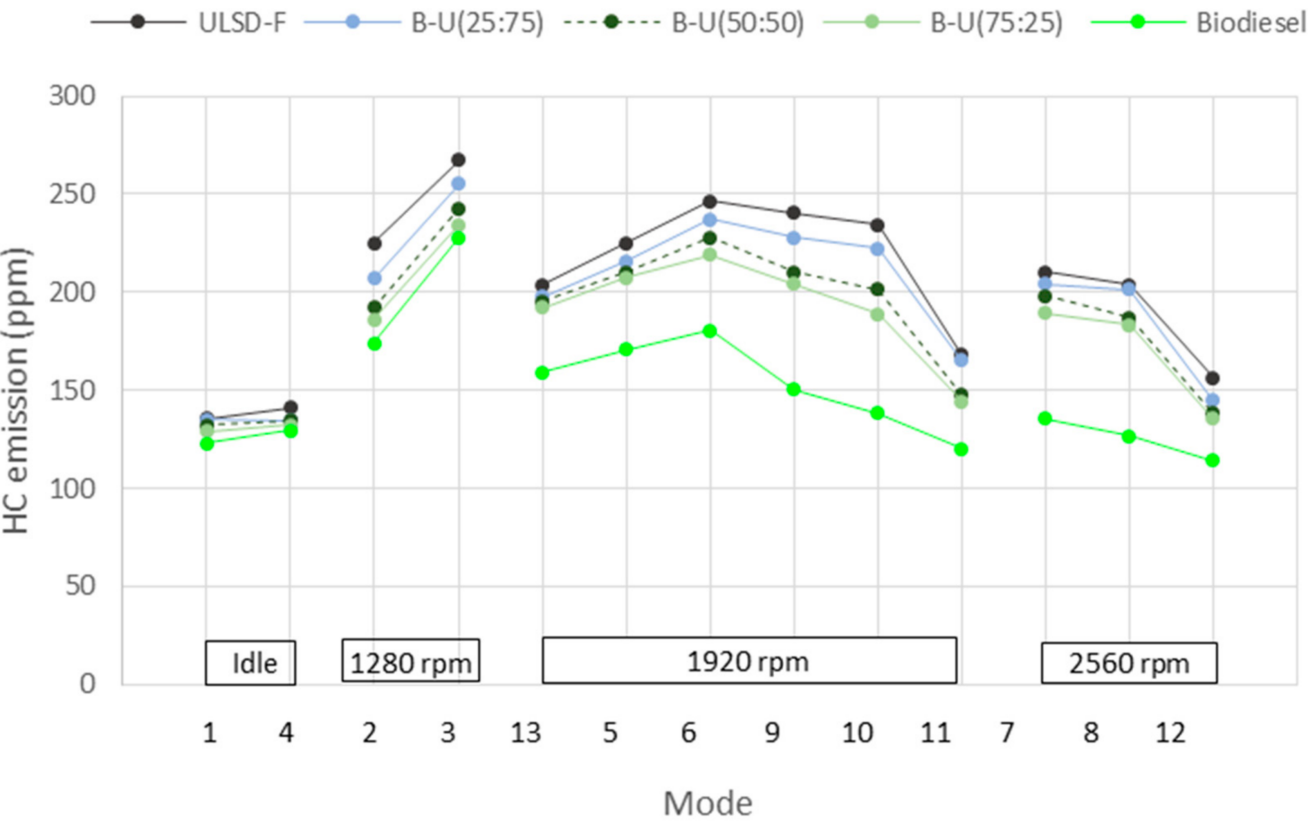

Figure 3. Experimental fuels and the HC emissions.

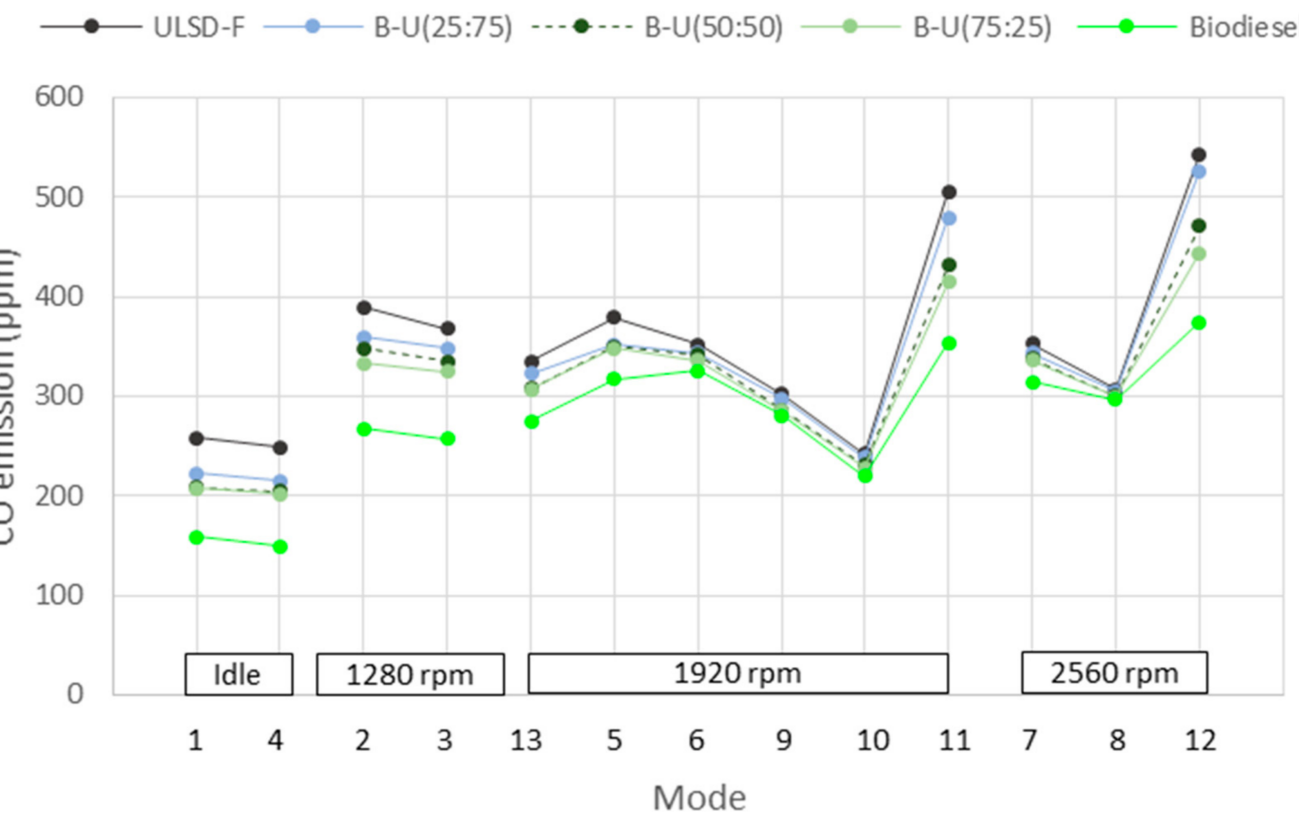

Figure 4. Experimental fuels and the $\mathrm{CO}$ emissions. 


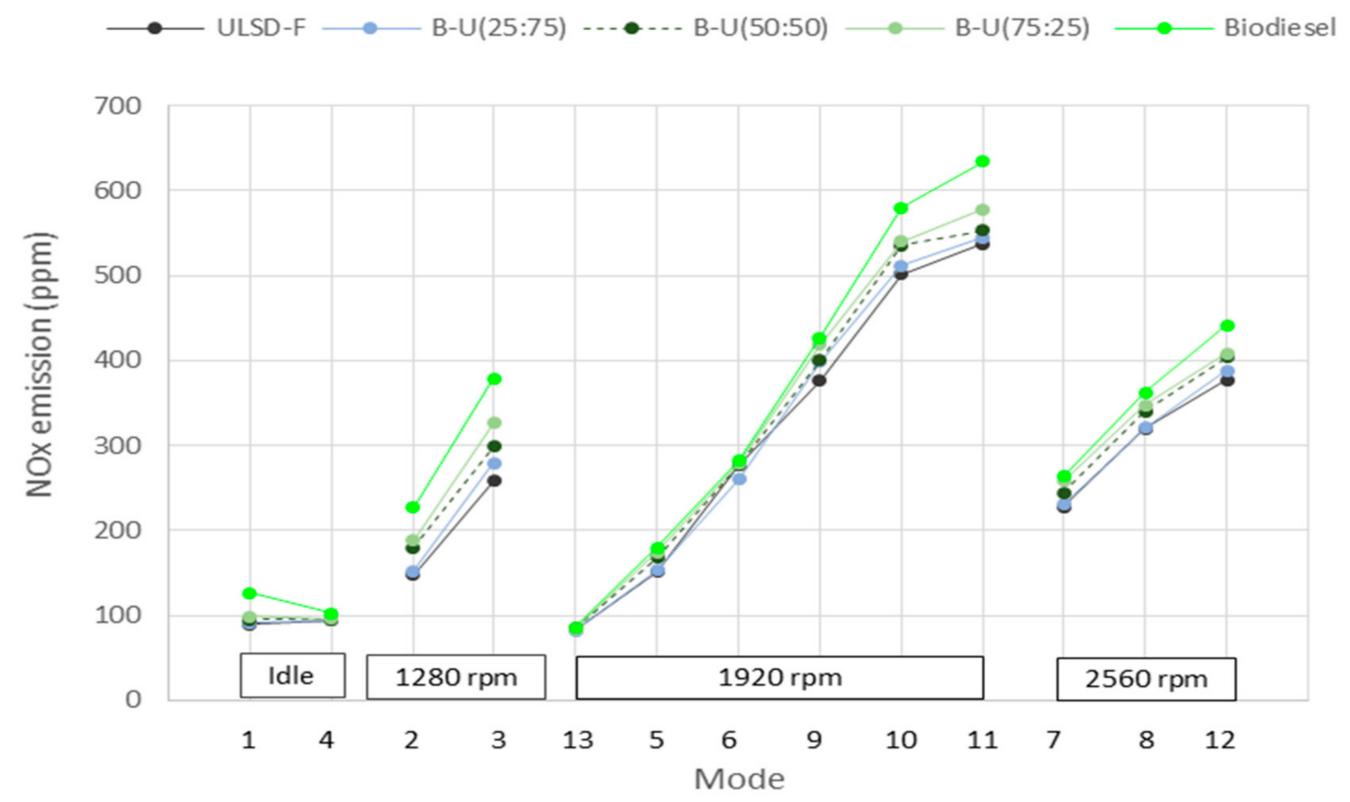

Figure 5. Experimental fuels and the $\mathrm{NO}_{\mathrm{X}}$ emissions.

It can be stated, according to the measured data, that the profile of HC emissions reaches its maximum at the average engine speed of $1920 \mathrm{rpm}$ in the case of medium engine loading and for both types of fuels (100\% diesel fuel and biodiesel). However, it should be also mentioned that in the case of low engine loading levels and at the engine speed of $1280 \mathrm{rpm}$, the HC emissions increased with higher engine loading; thereby, the HC emissions were reduced at high engine loading levels and at the engine speed of $2560 \mathrm{rpm}$. A similar situation was also recorded at engine speeds of $1920 \mathrm{rpm}$ and $1280 \mathrm{rpm}$. In this case, the HC emissions increased if the engine loading raised from $20 \%$ to $40 \%$. Higher fuel consumption causes also a higher amount of $\mathrm{HC}$ emissions. At the same time, the rising engine loading generates increased temperatures of the burned gas in the cylinder as well as increased temperature of the exhaust gases. In this way, there is also a reduced volume of the unburned fuel components. The HC emissions are lower at higher engine speeds thanks to the improved oxidation of $\mathrm{HC}$ due to the high level of the exhaust gas temperatures.

Analogous to the HC emissions, we can say that a higher amount of biodiesel reduces the $\mathrm{CO}$ emissions, according to Figure 4.

It can be stated, according to the obtained results, that an increase in the $\mathrm{CO}$ emissions is essential in the operational modes 11 and 12, namely due to the higher value of the fuel/air ratio, which is necessary at a high engine loading level. At the same time, the CO emissions rise with the increasing engine speed. It is visible from Figure 4 that the addition of biodiesel to the standard diesel fuel causes an increase in $\mathrm{NO}_{\mathrm{X}}$ emissions. The generation of $\mathrm{NO}_{\mathrm{X}}$ emissions is a function of the local oxygen concentration, combustion temperature and ignition delay [10]. The engine operational mode has a significant influence on the combustion process temperature and thus it can significantly affect the amount of generated $\mathrm{NO}$ emissions. A higher engine speed at lower engine loading reduces $\mathrm{NO}_{X}$ emissions. On the other hand, higher engine loading requires a higher amount of the injected fuel, which causes higher combustion temperature and, finally, an increase in $\mathrm{NO}_{\mathrm{X}}$ emissions.

Figure 6 illustrates the particulate matter (PM) emissions in the operational modes 3 , $6,7,8,12$. The PM emissions are reduced in the case of a larger volume of biodiesel in the fuel mixture during the operational modes $6,7,8,12$. The reason for this reduction consists in the following factors: the absence of aromatic content in biodiesel and the presence of oxygen in biodiesel, which improves the oxidation of the carbon particles. 


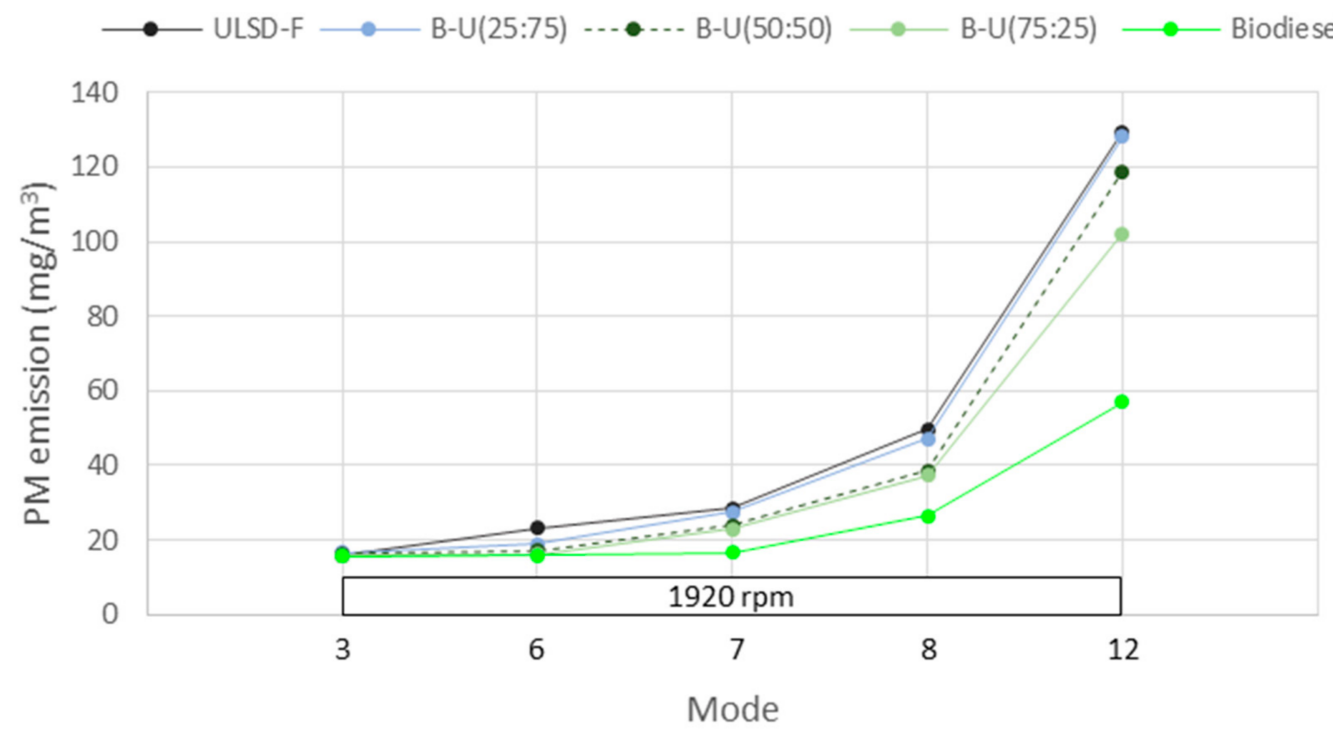

Figure 6. Experimental fuels and the PM emissions.

The PM emissions increase with higher engine loading due to a larger amount of the injected fuel. Another relevant factor for the increase in PM emissions is the higher engine speed level, which causes a decrease in the volumetric efficiency [13]. The reduced volumetric efficiency means the higher AFR value, which leads to the production of PM emissions.

\subsection{The Unregulated Emissions}

The emissions of acetaldehyde and formaldehyde (Figures 7 and 8) grow with the increasing portion of biodiesel in the fuel mixture. This dependence is caused mainly due to the fact that short-chain chemicals, which are contained in the biodiesel produced from the home waste oil, are able to create the shortest carbonyl chain during the combustion process, i.e., acetaldehyde and formaldehyde [14].

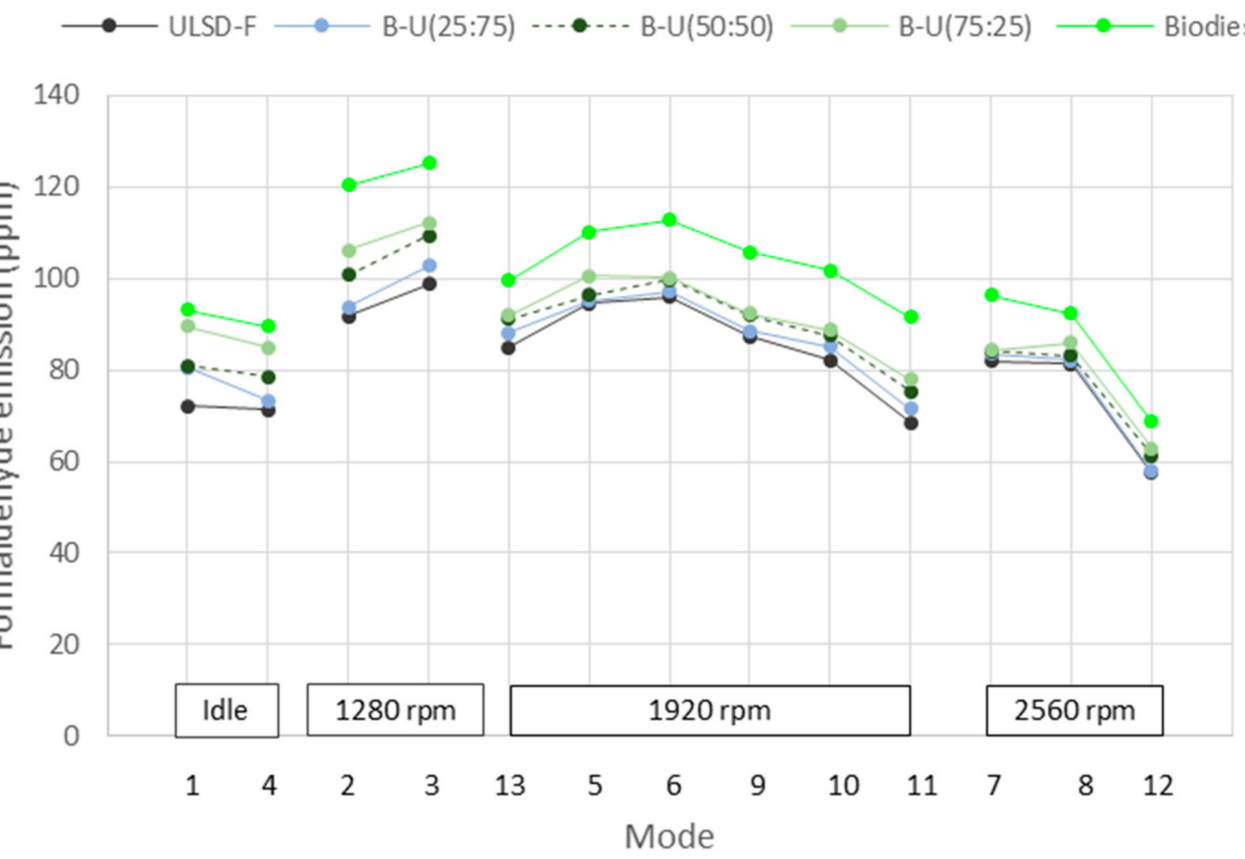

Figure 7. Experimental fuels and the formaldehyde emissions. 


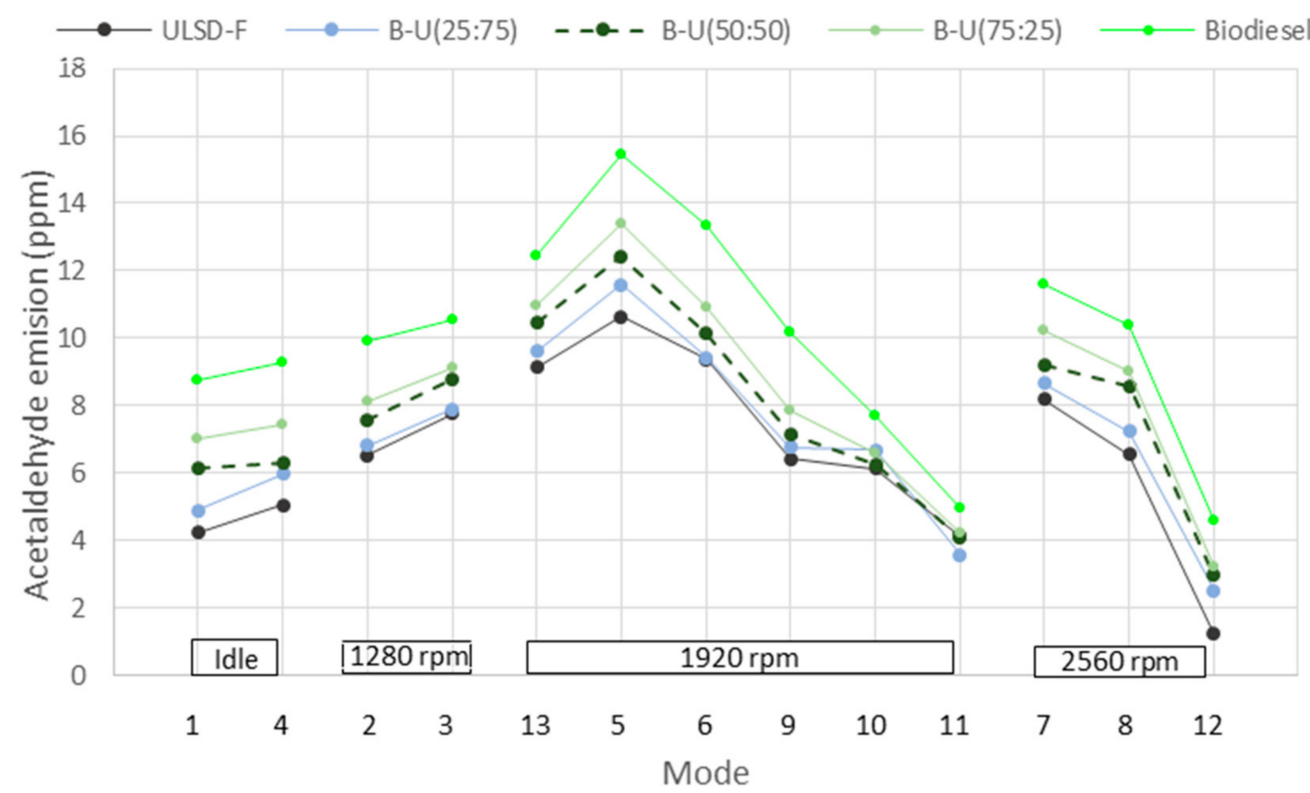

Figure 8. Experimental fuels and the acetaldehyde emissions.

At the same time, the operational or working conditions also have a major impact on these emissions. An increase in formaldehyde emissions was recorded within the interval from low to middle engine loading level. A decrease in this kind of emissions was monitored in the range from middle to high engine loading level and for all the tested fuels, according to Figure 7, at the engine speed $1920 \mathrm{rpm}$. The developed trend concerning acetaldehyde emissions is very similar, as seen in Figure 8. A higher volume of carbonyl emissions in the case of low engine loading level is caused due to increased fuel consumption. A reduction in these emissions at high engine loading level is a positive consequence of the rising combustion temperature as well as the exhaust gas temperature. Higher engine speed reduces acetaldehyde and formaldehyde emissions thanks to higher combustion temperatures.

The unsaturated alkenes, i.e., propene, ethene and 1,3-butadiene, are the chemical precursors of diesel soot. 1,3-butadiene is one of the most harmful substances that pollutes air with regard to its carcinogenic impact [15].

It is possible to say, according to the measured results presented in Figures 9-11, that the emissions of 1,3-butadiene grow with the increasing amount of biodiesel.

Emissions of the three above-described toxic substances are reduced in the case of increased engine loading, but their concentration rises during the operational modes 11 and 12 [16].

Taking into consideration the emissions of benzene, xylene and toluene (BXT), a phenomenon that just the unburned fuel molecules generate these kind of gaseous emissions is observed. Table 5 documents the influence of biodiesel on the BXT emissions in the operational modes 5, 9 and 11 within the 13-regime experimental test cycle at the engine speed $1920 \mathrm{rpm}$. Benzene emissions grow when the content of biodiesel in the fuel is higher, whereby this relation is valid in the case of every engine loading level. However, the emissions of xylene and toluene are reduced if the volume of biodiesel is increased [16]. 


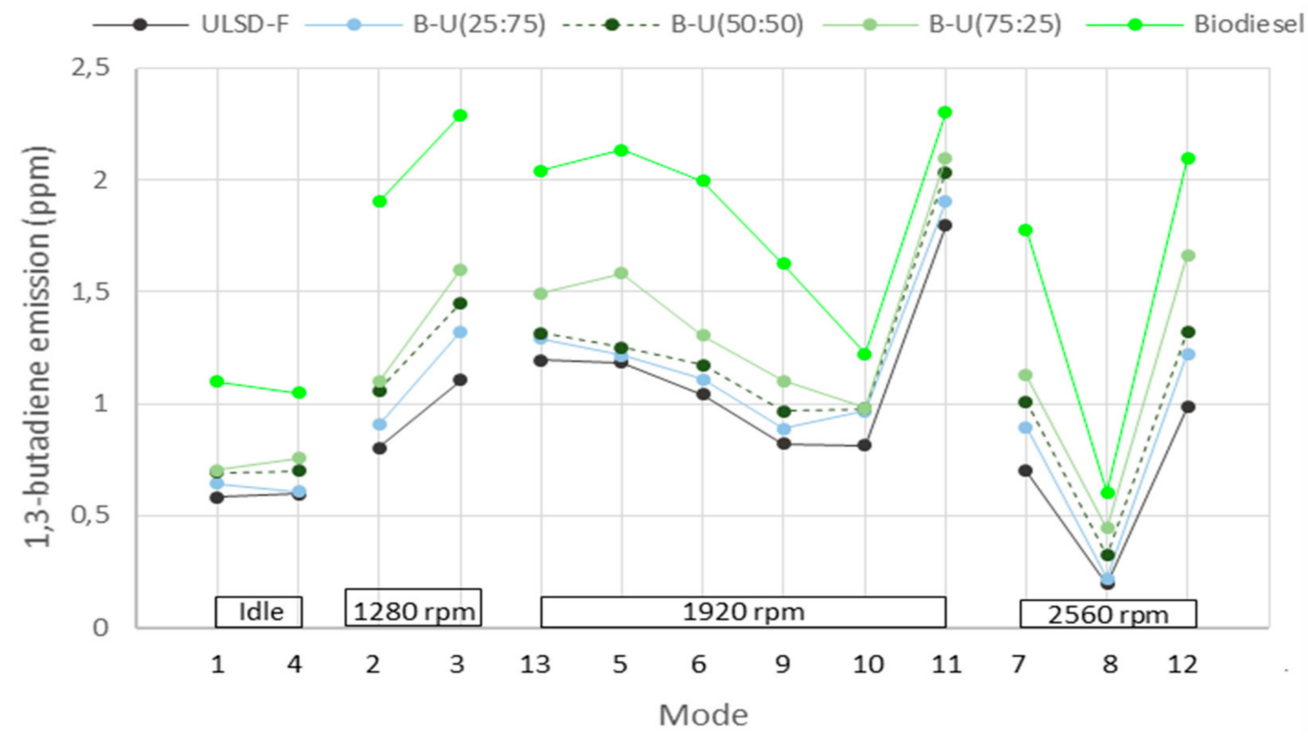

Figure 9. Experimental fuels and the 1,3-butadiene emissions.
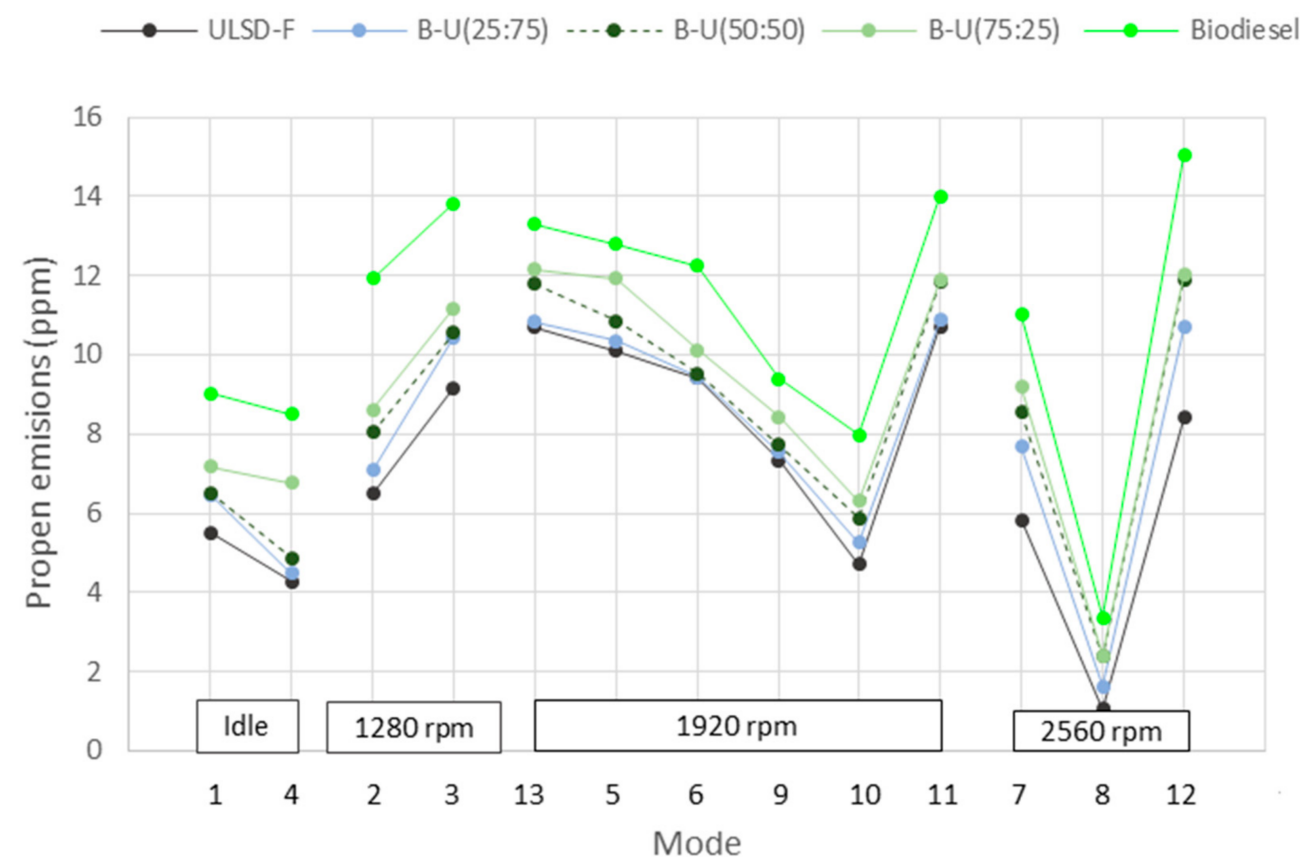

Figure 10. Experimental fuels and the propene emissions.

The total amount of BXT emissions is based on the measured data and is summarized in Table 5. The global volume of BXT emissions is lower if the engine loading increases, at the engine speed of $1920 \mathrm{rpm}$, because the higher temperature of the combustion process (due to higher level of engine loading) improves the oxidation process of the BXT emissions. The analogous results were obtained using another two engine speed levels: $1280 \mathrm{rpm}$ and $2560 \mathrm{rpm}$. However, no relevant influence of the engine speed on BXT emissions was monitored. 


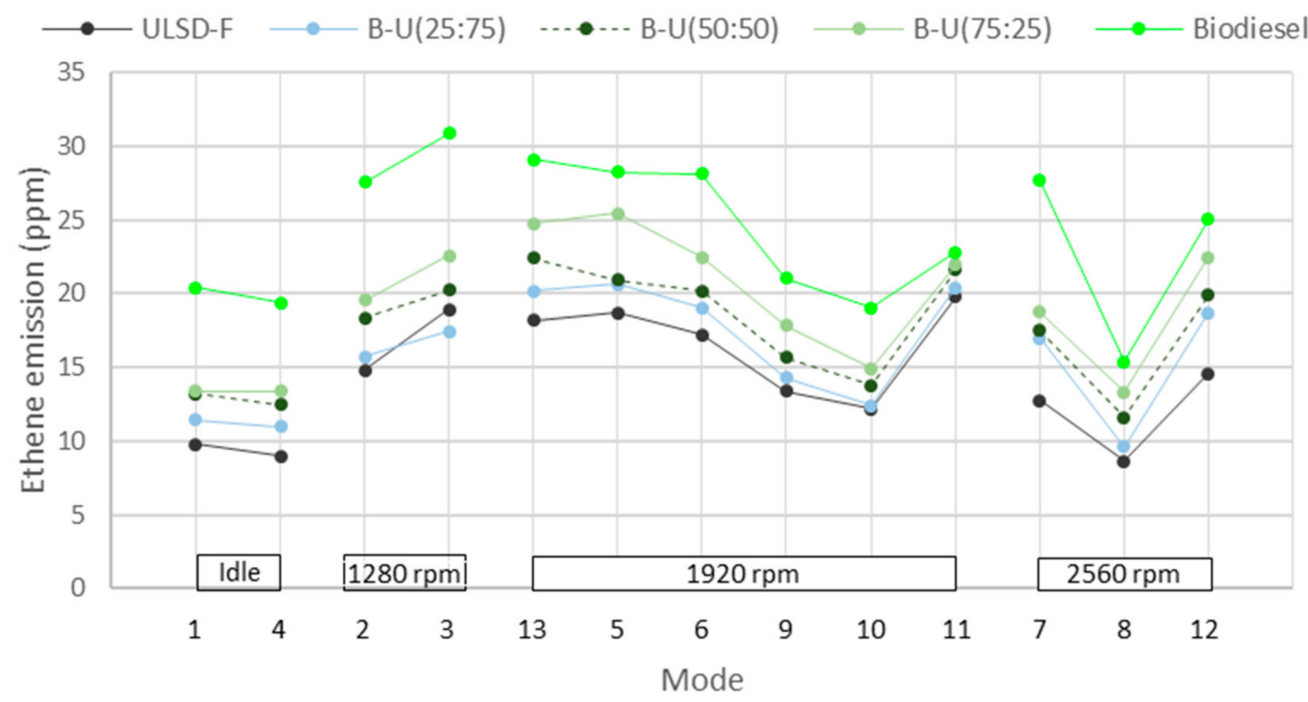

Figure 11. Experimental fuels and the ethene emissions.

Table 5. The benzene, toluene and xylene emissions.

\begin{tabular}{|c|c|c|c|c|}
\hline Mode & Fuel & $\begin{array}{c}\text { Benzene } \\
\text { (mg/kWh) }\end{array}$ & $\begin{array}{c}\text { Toluene } \\
\text { (mg/kWh) }\end{array}$ & $\begin{array}{c}\text { Xylene } \\
\text { (mg/kWh) }\end{array}$ \\
\hline \multirow{5}{*}{5} & ULSD-F & 79.0 & 9.5 & 34.1 \\
\hline & B-U (25:75) & 83.8 & 8.2 & 27.0 \\
\hline & B-U (50:50) & 88.2 & 6.7 & 22.7 \\
\hline & B-U (75:25) & 91.5 & 5.4 & 20.2 \\
\hline & Biodiesel & 95.1 & 4.3 & 8.5 \\
\hline \multirow{5}{*}{9} & ULSD-F & 43.2 & 3.6 & 12.8 \\
\hline & B-U (25:75) & 44.3 & 3.0 & 9.9 \\
\hline & B-U (50:50) & 45.9 & 2.5 & 8.0 \\
\hline & B-U (75:25) & 47.2 & 2.0 & 5.9 \\
\hline & Biodiesel & 49.8 & 1.7 & 3.5 \\
\hline \multirow{5}{*}{11} & ULSD-F & 21.0 & 1.7 & 5.3 \\
\hline & B-U (25:75) & 22.1 & 1.5 & 4.2 \\
\hline & B-U (50:50) & 22.5 & 1.4 & 3.1 \\
\hline & B-U (75:25) & 23.4 & 1.2 & 2.5 \\
\hline & Biodiesel & 25.2 & 1.0 & 1.8 \\
\hline
\end{tabular}

\section{Conclusions}

The article is focused on the influences of biodiesel, which is mixed with standard diesel fuel, and on gaseous emissions (both on regulated and unregulated) in the case of diesel engine, taking into consideration the infamous emission scandal, named "dieselgate". The results of the experiments performed with the fuel mixture biodiesel-diesel, concerning the controlled emissions, point out a relevant fact that during all the engine operational modes, $\mathrm{CO}$ emissions and also hydrocarbon emissions were reduced, and $\mathrm{NO}_{X}$ emissions were increased in comparison with the combustion of pure diesel fuel.

With regard to the unregulated emissions, it was noted that the emissions of acetaldehyde and formaldehyde increased together with the growing volume of biodiesel contained in the fuel mixture. An analogous situation is also characteristic for the emissions of propene, ethene and 1,3-butadiene. Biodiesel also increases benzene emissions, but at the same time it also reduces xylene and toluene emissions. However, no significant 
changes relating to the BXT emissions were monitored, thanks to the fact that a higher volume of benzene emissions were simultaneously compensated by the lower xylene and toluene emissions. It is important to emphasize the reality that gaseous emissions, whether regulated or unregulated, are predominantly influenced by engine operational modes that are required according to the changing engine loading [17].

Author Contributions: Conceptualization, M.P. and M.K.; methodology, M.P. and J.Ž.; investigation, Š.K. and M.L.; data analysis, M.P. and M.L.; writing-original draft preparation, J.Ž. and M.K.; writing-review and editing, M.L. All authors have read and agreed to the published version of the manuscript.

Funding: This work was supported by the Slovak Research and Development Agency under the Contract no. APVV-19-0328. The article was written in the framework of Grant Projects: VEGA $1 / 0318 / 21$ "Research and development of innovations for more efficient utilization of renewable energy sources and for reduction of the carbon footprint of vehicles", KEGA 006TUKE-4/2020 "Implementation of Knowledge from Research Focused on Reduction of Motor Vehicle Emissions into the Educational Process" and this work was supported by the Slovak Research and Development Agency under the contract No. APVV-16-0259.

Institutional Review Board Statement: Not applicable.

Informed Consent Statement: Not applicable.

Data Availability Statement: Not applicable.

Conflicts of Interest: The authors declare no conflict of interest.

\section{References}

1. Basha, S.A.; Gopal, K.R.; Jebaraj, S. A review on biodiesel production, combustion, emissions and performance. Renew. Sustain. Energy Rev. 2009, 13, 1628-1634. [CrossRef]

2. Utlu, Z.; Koçak, M.S. The effect of biodiesel fuel obtained from waste frying oil on direct injection diesel engine performance and exhaust emissions. Renew. Energy 2008, 33, 1936-1941. [CrossRef]

3. Wang, T.; Liu, J.; Sun, P.; Ji, Q.; Gao, W.; Yang, C. Influence of injection parameters on combustion, gaseous emissions and particle size distribution of a CRDI diesel engine operating with PODE/diesel blends. Fuel 2020, 281, 118733. [CrossRef]

4. Sinay, J.; Puškár, M.; Kopas, M. Reduction of the NOx emissions in vehicle diesel engine in order to fulfill future rules concerning emissions released into air. Sci. Total Environ. 2018, 624, 1421-1428. [CrossRef] [PubMed]

5. Puškár, M.; Jahnátek, A.; Kádárová, J.; Šoltésová, M.; Kovanič, L.; Krivosudská, J. Environmental study focused on the suitability of vehicle certifications using the new European driving cycle (NEDC) with regard to the affair "dieselgate" and the risks of NOx emissions in urban destinations. Air Qual. Atmos. Health 2019, 12, 251-257. [CrossRef]

6. Puškár, M.; Kopas, M.; Puškár, D.; Lumnitzer, J.; Faltinová, E. Method for reduction of the NOX emissions in marine auxiliary diesel engine using the fuel mixtures containing biodiesel using HCCI combustion. Mar. Pollut. Bull. 2018, 127, 752-760. [CrossRef] [PubMed]

7. Sharp, C.A.; Howell, S.A.; Jobe, J. The effect of biodiesel fuels on transient emissions from modern diesel engines, part II unreg-ulated emissions and chemical characterization. SAE Trans. 2000, 1784-1807. [CrossRef]

8. Agency, E.P. A Comprehensive Analysis of Biodiesel Impacts on Exhaust Emissions; US Environmental Protection Agency: Washington, DC, USA, 2002.

9. McGill, R.; Storey, J.; Wagner, R.; Irick, D.; Aakko, P.; Westerholm, M.; Nylund, N.-O.; Lappi, M. Emission Performance of Selected Biodiesel Fuels; SAE Technical Paper 2003-01-1866; SAE International: Warrendale, PA, USA, 2003. [CrossRef]

10. Di, Y.; Cheung, C.; Huang, Z. Experimental investigation on regulated and unregulated emissions of a diesel engine fueled with ultra-low sulfur diesel fuel blended with biodiesel from waste cooking oil. Sci. Total Environ. 2009, 407, 835-846. [CrossRef] [PubMed]

11. Lapuerta, M.; Armas, O.; Rodriguezfernandez, J. Effect of biodiesel fuels on diesel engine emissions. Prog. Energy Combust. Sci. 2008, 34, 198-223. [CrossRef]

12. Zouaoui, N.; Brilhac, J.-F.; Mechati, F.; Jeguirim, M.; Djellouli, B.; Gilot, P. Study of experimental and theoretical procedures when using thermogravimetric analysis to determine kinetic parameters of carbon black oxidation. J. Therm. Anal. Calorim. 2010, 102, 837-849. [CrossRef]

13. Tsolakis, A. Effects on Particle Size Distribution from the Diesel Engine Operating on RME-Biodiesel with EGR. Energy Fuels 2006, 20, 1418-1424. [CrossRef]

14. Guarieiro, L.L.N.; Pereira, P.A.D.P.; Torres, E.A.; Da Rocha, G.O.; De Andrade, J.B. Carbonyl compounds emitted by a diesel engine fuelled with diesel and biodiesel-diesel blends: Sampling optimization and emissions profile. Atmos. Environ. 2008, 42, 8211-8218. [CrossRef] 
15. Krahl, J.; Munack, A.; Schröder, O.; Stein, H.; Bunger, J. Influence of Biodiesel and Different Designed Diesel Fuels on the Exhaust Gas. Emissions and Health Effects. SAE Trans. 2003, 112, 2447-2455.

16. Takada, K.; Yoshimura, F.; Ohga, Y.; Kusaka, J.; Daisho, Y. Experimental Study on Unregulated Emission Characteristics of Tur-Bocharged DI Diesel Engine with Common Rail Fuel Injection System; SAE Technical Paper 2003-01-3158; SAE International: Warrendale, PA, USA, 2003. [CrossRef]

17. Kuric, I.; Cisar, M.; Tlach, V.; Zajacko, I.; Gál, T.; Więcek, D. Technical diagnostics at the department of automation and production systems. In International Conference on Intelligent Systems in Production Engineering and Maintenance; Springer: Cham, Switzerland, 2019; Volume 835, pp. 474-484. 